\title{
FAMILY SYSTEMS AND FAMILY VALUES IN TWENTY-FIRST-CENTURY HUNGARY
}

\author{
Csaba Dupcsik and Olga Tóth
}

\section{1 'Mapping' Hungary between West and East}

There is a very influential view that the border of the Western culture (at least in the Middle Ages and early modern times) runs along the line of Western and Eastern Christianity (by and large coinciding with the eastern borders of historic Hungary and the historic Polish core territory). ${ }^{1}$ Another influential view also exists about the historical inner borders of Europe: that the territory lying east of the Elbe and Leitha rivers have been a region with 'mixed' Western and Eastern (European) characteristics in the cultural, social, political senses. The most important piece of information necessary to define Hungary's position is on the map: this country lies between these 'borders'.

In early modern times Hungary was a part of the Habsburg Empire in some periods as a rebellious and repressed region, in other times as a half-autonomous country, which in the last half of the nineteenth century was a formally independent and equal co-state within the Empire. With the collapse of the Austro-Hungarian Empire in 1918-20 Hungary's territory has reduced by two-thirds (nowadays it is about 93,000 square kilometres; the population is about ten million). Between 1945 and 1990 the country was under Soviet occupation, and its political, economic, and social systems were transformed into state socialism. After 1990 the country became a democracy and a member of NATO (1999) and the European Union (2004).

\subsection{Between the 'European' and 'non-European'Family Models}

Last but not least there is a third line which is important in the perspective of this: the so-called Hajnal's line. Writing about marriage and family, John Hajnal differentiated 'the European model' (which is characterised by relatively late marriage age, high non-marriage rate, low

\footnotetext{
${ }^{1}$ South-east of this border is the Balkans, and eastwards is Eastern Europe. We use these terms as labels for macro-regions which have relevance in respect of social history, but this border definition does not intend to exclude these regions from contemporary European integration.
} 
fertility rate, and nuclear families), and the 'non- European model' (which is characterised by relatively early marriage age, low nonmarriage, high fertility rates and extended families). The historical demographer drew an imaginary line from St Petersburg (Russia) to Trieste (now Italy, but in the early modern times belonging to the Habsburg monarchy) which divided Europe into two parts by these two models. ${ }^{2}$ That could imply that Hungary or the greater part of the historical country fell east of this social historical border. If we accept Hajnal's idea, Hungary belonged to the 'non-European model' with all its features. However, in contrast with this argument other social historians' research $^{3}$ has pointed out that the situation of Hungary was more complicated. ${ }^{4}$ Despite being socially, ethnically, and regionally differentiated, in large parts of the country the nuclear family was prevalent even in early modernity (however, with lower marriage age and higher marriage rates than Western Europe).

To sum up, in the nineteenth century, Hungary showed the features of both Hajnal's 'European' and 'non-European' marriage models at the same time.

\subsection{Between the 'First Modernisation' and the 'Compressed Modernisation'}

It is also not easy to typify Hungarian modernity. The tenets of modernisation such as industrialisation, urbanisation, marketisation, etc. began to emerge on one hand later than in Western Europe, but on the other hand they were still beginning to emerge even in the nineteenth century.

Although it seems there is no perfect index for characterising the modernisation process, the rate of employment in agriculture can be useful in this regard. This rate, which was above $80-90$ per cent in every pre-modern society, ${ }^{5}$ began to diminish in England in the eighteenth century, and in some Western European countries (Belgium, France) in the first half of the nineteenth century. Meanwhile in a number of countries described as being 'late modernisers' this rate began to diminish rapidly in the second half of the twentieth century.

\footnotetext{
2 Hajnal (1965).

3 For example that of Andorka and Faragó (1983) and Faragó (1999).

4 Later even John Hajnal seemed to accept their argument (Hajnal 1983, 92).

5 Of course this was less in smaller city-states.
} 


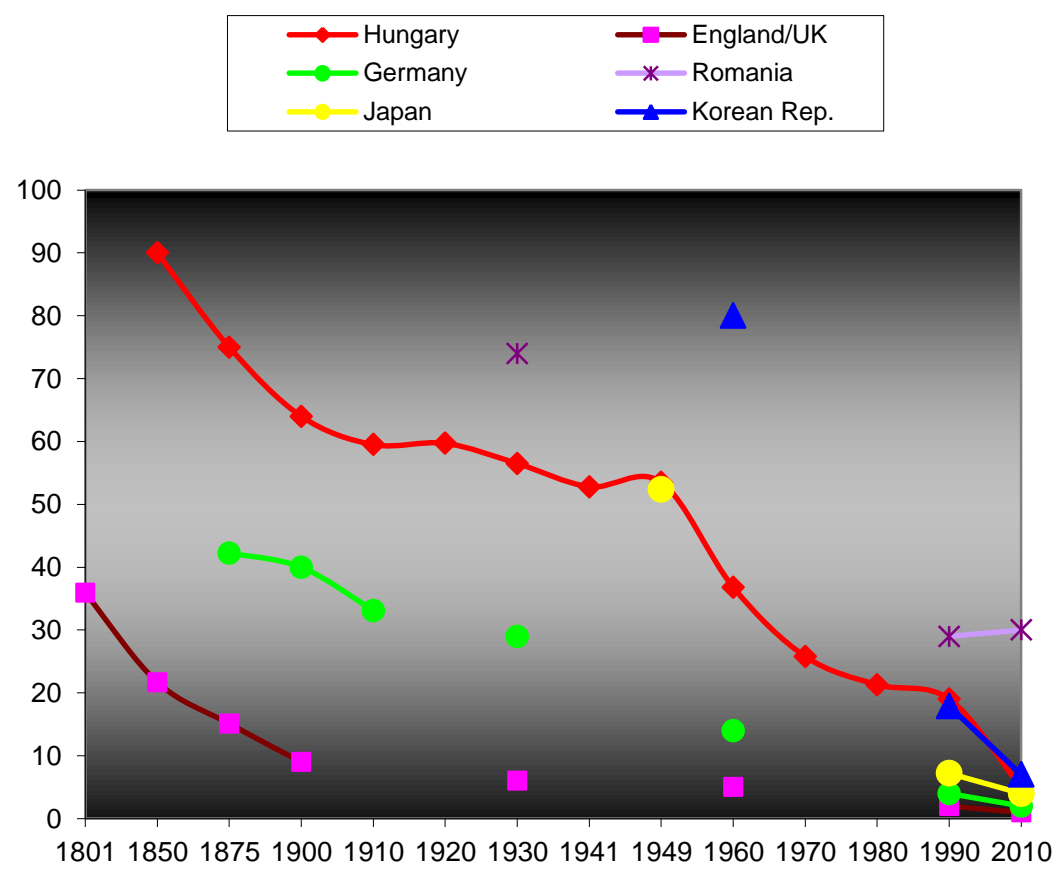

Figure 1. Agricultural employment in selected countries, 1801-2000 (percentage of total employment). Source: Berend and Ránki (1976, 481; 1987, 26); Diedericks et al. (1995, 199, 205); Diószegi et al. (1997, 145); Gergely (2003, 345); Hungarian Statistical Office; World Bank World Development Indicators.

Although the data set presented in Figure 1 does not conclusively prove anything in itself, it perhaps demonstrates our thesis that the development trajectory of Hungary can be situated between the countries of 'First Modernisation' (typical of some Western European countries) ${ }^{6}$ and those of 'Compressed Modernisation' (typical of most countries on all continents). ${ }^{7}$ The modernisation in Hungary began relatively early, but the process always dropped behind Western Europe, which was always the most important point of reference for the country. On the other hand the process was disrupted and distorted at several periods in the twentieth century.

\footnotetext{
${ }^{6}$ Berend and Ránki (1987).

${ }^{7}$ Chang $(2003,2010)$.
} 
For our understanding of the present situation there is a special significance to the distortion caused by the forced modernisation of the Communist regimes between 1945 and 1990. The social and economic policy of this established a system which turned out to be dysfunctional in many areas at the same time. For example, the economic system was out of date from the beginning because it preferred heavy industry over the service and the knowledge-based sectors; the economy continuously produced and reproduced shortages, meanwhile systematically lavished with resources (raw materials and labour). ${ }^{8}$ From the perspective of our study two aspects require special attention: (1) Due to the dominant ownership of the state and because of the shortages in the economy, ${ }^{9}$ enterprises were insensitive to costs, and they tried to store every kind of resource including manpower; and (2) this endeavour produced almost full employment amongst both men and women. One of the key issues of the familist discourse (see Figure 2), namely the statement that female paid work emerged in the age of state socialism, can be considered a myth if we examine the long-term tendencies.

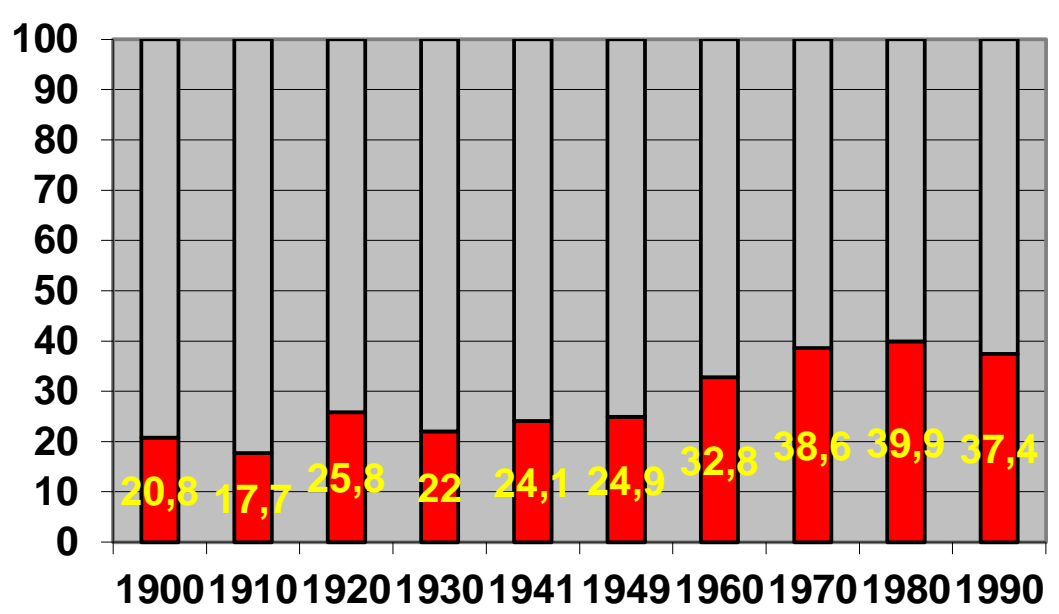

Figure 2. Actively employed women, 1900-1990 (percentage of all women). Source: Hungarian Statistical Office.

Of course the age of state socialism brought some major changes. Perhaps the most relevant change was constrained industrialisation and the forced reorganisation of the agriculture, which pushed women into

\footnotetext{
8 Kornai (1980).

9 Ibid.
} 
the labour market. The rate of employment and full-time education amongst women increased such that by 1980 amongst females aged between fifteen and fifty-four years, only 6.8 per cent were housewives. $^{10}$

Summing up, the familist argument that the socialist system forced women into the workplace is not a totally false statement, but it is exaggerated. Before 1945 most women had paid work (or worked on their family land) for at least some period of their life. The change after 1945 had been drastic for middle-class women only, and this strata, the former middle class, could be considered as one of the losers in the Communist takeover, as one of the 'class enemies' of the new system. It is noteworthy that despite state discrimination in the first period of socialism, most children and grandchildren of the former middle class were able to rekindle their family's middle-class status. On the one hand this process of status reproduction is a revealing example that social familism could run as a very efficient mechanism on the micro-level: despite affirmative action for workers' children and political and administrative discrimination against children of the former middle class, members of latter category still had a greater chance of becoming intellectuals ${ }^{11}$ or 'socialist entrepreneurs, ${ }^{12}$ with the help of cultural capital inherited from their family. On the other hand, the experiences and family traditions of this social group also had relevant influences on the later familist discourse.

Due to the low level of efficiency of the state economy there was a (quasi) market 'second economy' in practically every European socialist country, but in Hungary it was present in a particularly extended way. ${ }^{13}$ In the latter days of socialism in three-quarters of all families at least one member participated in this second economy, but, with a few exceptions, largely as a part-time worker while they were also full-time employees of the state. ${ }^{14}$ This structure implies a more or less conscious restriction of their commitments and endeavours in the state sector, and selfexploitation in the second economy. Furthermore the toleration and partial legalisation of the second economy was not equal to its legitimisation - on the contrary the official discourse insisted that private ownership and the market, even in this restricted form, were only temporary concessions.

\footnotetext{
10 Andorka and Harcsa (1990, 94).

11 Kemény (1990, 116-17).

2 Szelényi (1988); Manchin and Szelényi (1990).

3 Gábor and Galasi (1981).

14 Kolosi (1987).
} 


\subsection{Modernisation and Trust}

Due to their particular position inside the Habsburg Empire, until 1918 the majority of Hungarians had ambivalent attitudes towards Hungarian institutions, including the government: they viewed them as both their own home institutions and as agents of a foreign power at the same time. ${ }^{15}$ In the following periods, between 1914 and 1990, there were two world wars, ${ }^{16}$ three military occupations, two revolutions (both repressed), genocides, red and white terrors, great territorial rearrangements, violently driven social restructuring, and there were nine changes of political system. ${ }^{17}$ Until 1990 no regime was democratic and in practice all governments treated one or some groups of society as hostile. In all likelihood there are very few families in Hungary who have no family members who victims of state discrimination for a while. The forced social changes between 1945 and 1960 in themselves reinforced the distrust of institutions and (re)produced a crisis of values.

According to the European Values Study survey, the level of trust in institutions in 1991 was diminished significantly compared to 1982, since when the decrease has been continuous but smaller. ${ }^{18}$ We have to take with a grain of salt the measurement of trust level in the situation of the single-party dictatorship: in those times any 'trust' which existed would be partly mimicry, partly a response to the feeling of stability, and the expectation that this system would last 'forever' (these expectations, of course, are hardly separable from 'real' trust). In the second half of 1989 when the Soviet camp in Central Europe collapsed, the level of distrust mushroomed, partly because the former latent mistrust became open, partly because the feeling of stability quickly vanished. ${ }^{19}$

Developments since 1989-90 have not contributed to the reconstruction (or construction) of general social trust. A lot of people expected the change of political system to usher in not only freedom but also a standard of living similar to that of Western European countries. However, even in the Central European region Hungary's achievement has been the worst in the area of economic growth. The state has withdrawn from the control of production, but state redistribution invariably plays an important role for family incomes. ${ }^{20}$ The

\footnotetext{
${ }^{15}$ However, both approaches had some relevance.

${ }_{17}^{16}$ Hungary was defeated in both world wars.

${ }^{17}$ Some amongst these systems were very short-lived, but the two longest, the Horthy and the Kádár régimes, were radically different in their beginnings, 'golden ages', and twilights.

${ }_{18}$ Hajdu (2013).

${ }^{19}$ Giczi and Sik (2009).

${ }^{20}$ Szalai (2007).
} 
government's policy is too paternalistic to be in accordance with democratic standards, which has generated discontentment amongst people. However most people are also unhappy with the state's attempt to withdraw from its former roles in the social, educational, cultural, and health spheres. These two groups overlap to a great extent and they constitute the decisive majority of Hungarian society.

When looking at Hungary it is relevant the sociologist Ságvári's note: 'To build a culture of trust requires a slow process with many small steps, meanwhile distrust's solidification into a cultural norm can occur far faster, in the wake of some relevant event experienced directly or indirectly. ${ }^{, 21}$ In Hungary, distrust apparently became a solid cultural norm even in the earlier periods of the twentieth century, and the recent era since 1990 has 'only' reproduced this culture through marketisation and political conflicts. This distrust culture is probably present in other countries too thathave similar conditions, namely the traditions of distrust and current social and political situations that are not suited to the building a culture of trust. According to the fourth wave of the European Social Survey in 2008-9, amongst thirty countries Hungary was twenty-second in the generalised level of trust. ${ }^{22}$ It is noteworthy that all except one of the last twelve countries on this scale are located in the Balkans or Eastern Europe, or are post-Communist Central European countries. This low level of trust can enhance the phenomenon of familism (see below) directly or, due to the weakness of civil society, indirectly in every society. ${ }^{23}$

To sum up, the situation is as follows: low levels of trust in institutions including the state; governments making paternalistic endeavours, but without the tools to maintain the formerly present level of social policy; a general distrustful habitus which tends to work in a self-confirming way; and a continuous crisis in terms of values. Familism is one of the social and individual reactions to this long and complex crisis.

\subsection{From Traditional Pluralism to the Post-War Standard Family}

Relevant to the aims of this chapter it should be stressed that in early modern times in Hungary there prevailed a kind of traditional pluralism in the realm of the family structure, and this pluralism lasted until the middle of the twentieth century. As Faragó ${ }^{24}$ argued, the Hungarian people adapted their marriage and family forms to changes in the

\footnotetext{
21 Ságvári (2013).

22 Hajdu (2013).

23 Fukuyama (1995); Torsello (2004); Tóth and Dupcsik (2012).

24 Faragó (1999).
} 
economy and society in a very 'plastic' way. He showed that during the period 1787-1828 the ratio of extended families increased somewhat in Hungary. At the beginning of the period more counties were characterised by the nuclear family and during the following four decades this ratio changed. Two different causes stand behind the very same demographic behaviour. By the end of the eighteenth century an overpopulation crisis emerged in Hungary (just like in other Western European countries). In the northern counties the overpopulation was coupled with a lack of land. Peasant families tried to protect themselves from pauperisation by using birth control and also through keeping young couples inside their original families, thus forming extended families. In contrast, in the southern part of the country peasant families could get more new land, but without the modernisation of farming they needed more hands to cultivate them. Founding extended families seemed to be an appropriate solution to get more labour. Both cases demonstrate the strong effect of belated modernisation on family structures.

The 'uniformisation' of family structure happened in the first two to three decades of the post-war period: this chapter will name the result of this process the Post-war Standard Family, or PSF. The most important characteristics of this model were as follows:

1. The overwhelming majority of the population got married (the proportion of never-married persons was lower than 5 per cent).

2. Marriage began at a relatively early age (in 1970 the male mean age at first marriage was 24.5 years and the female age was 21.6 years) and this was taken for granted as a norm and the prevailing practice. Cohabitation without marriage was regarded as a deviant lifestyle, practised mainly by undereducated people. It was also exceptional that young adults formed a one-person household.

3. The number of divorces reached a relatively high number by the 1970s and remained at this level, but the majority of divorced persons aspired to remarry.

4. The majority of couples had children, although significantly fewer children than in former decades.

In the 'golden age' of the PSF, which lasted from 1960 to the mid-1980s, the rate of marriage amongst males aged fifteen or over reached 70-72 per cent. This ratio was $60-62$ per cent in the first half of the twentieth century. Similar data for women were lower because of their higher life expectancy and their lesser chance of remarrying after divorce. 
The Hungarian PSF had some similarities with the post-war Western or Japanese family, ${ }^{25}$ but there was a significant difference too: in Hungary this period was not 'the age of housewives'. On the contrary, under state socialism (1945-90) typically both husbands and wives were full-time wage-earners as employees of the state (see data below). The reason was the socialist system's insensitivity to the cost of labour (which generated eagerness for every kind of employment) and depressed wages (which made it almost impossible for most families to make a living from a single income).

In return for acceptance of low wages, the state ran an extended social service system and tolerated people's activity in the second economy for additional income. The wage policy and social policy of the state economy was of outstanding importance for family formation, as married people were preferred to the unmarried. A single person had a minimal chance of getting an apartment through state distribution and the low level of the average income made it impossible to accumulate enough money to rent or buy a flat via market sources. Every policy and social institution pushed people to start a family. In other words, social familism played important role in people starting a family.

To summarise: the Hungarian PSF was a relatively modern type of family with some traditional features. The overwhelming majority of the population was living in families which were made up of married couples (two wage-earners) and two children.

\section{The Post-PSF Situation or the New Pluralism of Family Forms}

\subsection{Marital Status}

The new pluralisation of family forms started in the mid-1980s, and this process has continued to the present time. The changing structure of the economy, the broadening possibilities for enrolment in university, the growing career opportunities for both young men and women on the one hand and unemployment and growing inequalities on the other hand all had some effect on family forms. Not only real factors but attitudes and values have also changed during the last thirty years. However, when studying the practice of gender and family roles and the relevant attitudes, a peculiar contradiction emerges: while in terms of several real factors the Hungarian population belongs to the more modern segment on the (diverse) field of Europe, in terms of ideals the Hungarian population takes the opposite position. Hungary is one of the countries

\footnotetext{
${ }^{25}$ Ochiai (1996).
} 
where respondents agree to the greatest extent with traditional attitude statements concerning family and the roles of men and women - in certain respects not only by international comparison but in absolute number too. These facts have been demonstrated in the past decade by several different studies. ${ }^{26}$ As a result of these complex effects a more pluralistic picture can be drawn about the Hungarian family in 2010. This chapter shows the most relevant changes concerning family forms and attitudes and also the gaps between these attitudes and real demographic behaviour.

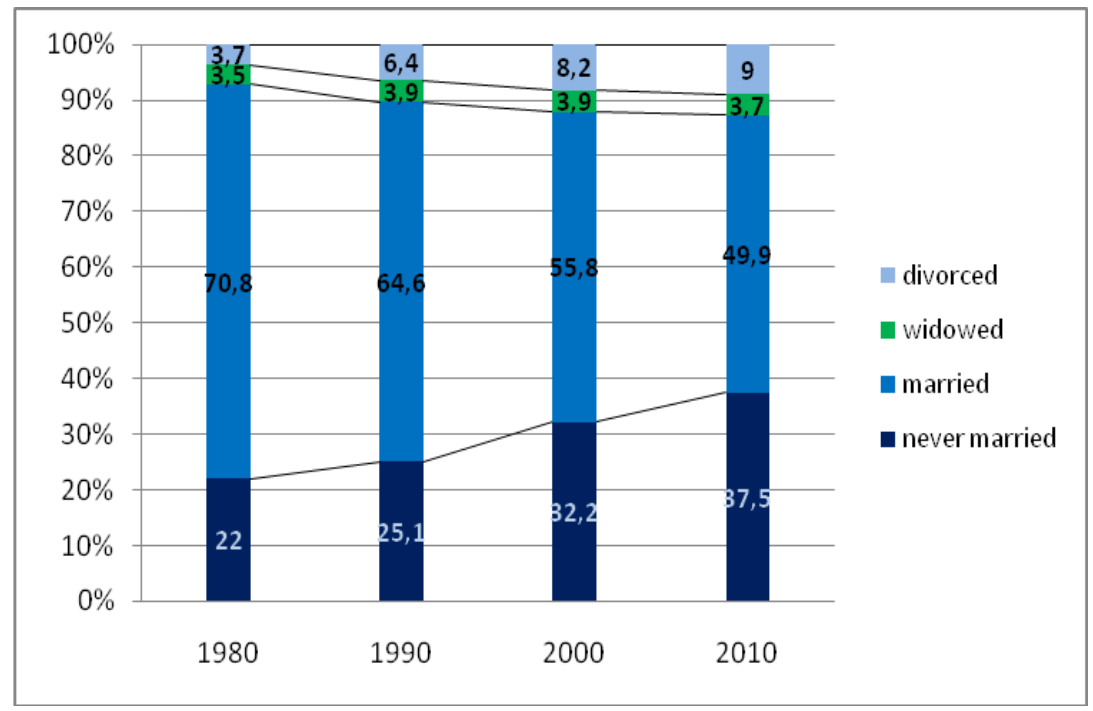

Figure 3. Percentage of males (fifteen years and older) by marital status, 1980-2010. Source: Demographic Yearbook (2010).

${ }^{26}$ See Tóth (1998); Pongrácz et al. (2001); Pongrácz and Spéder (2003); Blaskó (2006). 


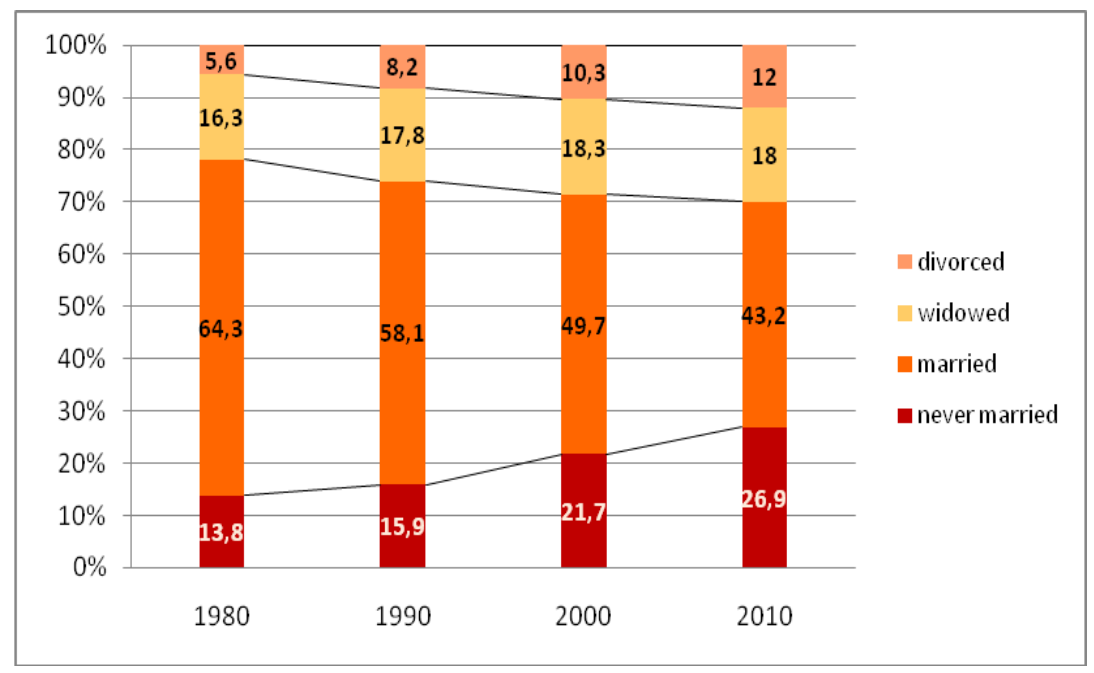

Figure 4. Percentage of females (fifteen years and older) by marital status, 1980-2010. Source: Demographic Yearbook (2010).

Figures 3 and 4 present the changes in marital status in a very obvious way. Since 1980 (the 'golden age of the PSF') the ratio of married persons has dramatically decreased amongst men and women. In the whole adult population, 20 per cent fewer married persons can be found now than thirty years ago. On the other hand, the ratio of never-married persons has doubled in the case of females and also increased by 17 per cent for males. The growing rate of divorced persons is also a significant change. We have no exact data, just estimations, about the very different new types of partnership and family forms (cohabitation, LAT relation, mosaic families, etc.) as relatively little research is being directing towards these new partnerships and family forms. In the mainstream of Hungarian research on family issues these new forms are seen as some kind of 'deviant' practice, with the most important thing to consider being how it might be possible to make people turn back to the 'normal' forms of family.

There are no significant differences between the marital status of males living in towns or villages or in settlements with more or fewer inhabitants ${ }^{27}$. Regions with different levels of economic development also do not show different types of marital status in the case of males. The only slightly significant difference can be found in the ratio of

\footnotetext{
27 Demographic Yearbook (2010)
} 
divorced men. This is highest in middle-size towns where it reaches 10.3 per cent of males of fifteen years old and older. The lowest rate is in the communities with the fewest inhabitants (at 8.5 per cent).

On the other hand, the marital status of females does show differences by region and community type. As the data show, many more nevermarried females live in Budapest than in other cities and especially than in small villages. Conversely there are more married females amongst village inhabitants than in towns. Divorced females are living in higher numbers in Budapest and also in other big cities. The data show that relatively more young women remain unmarried or divorced in these urbanised communities than in other communities.

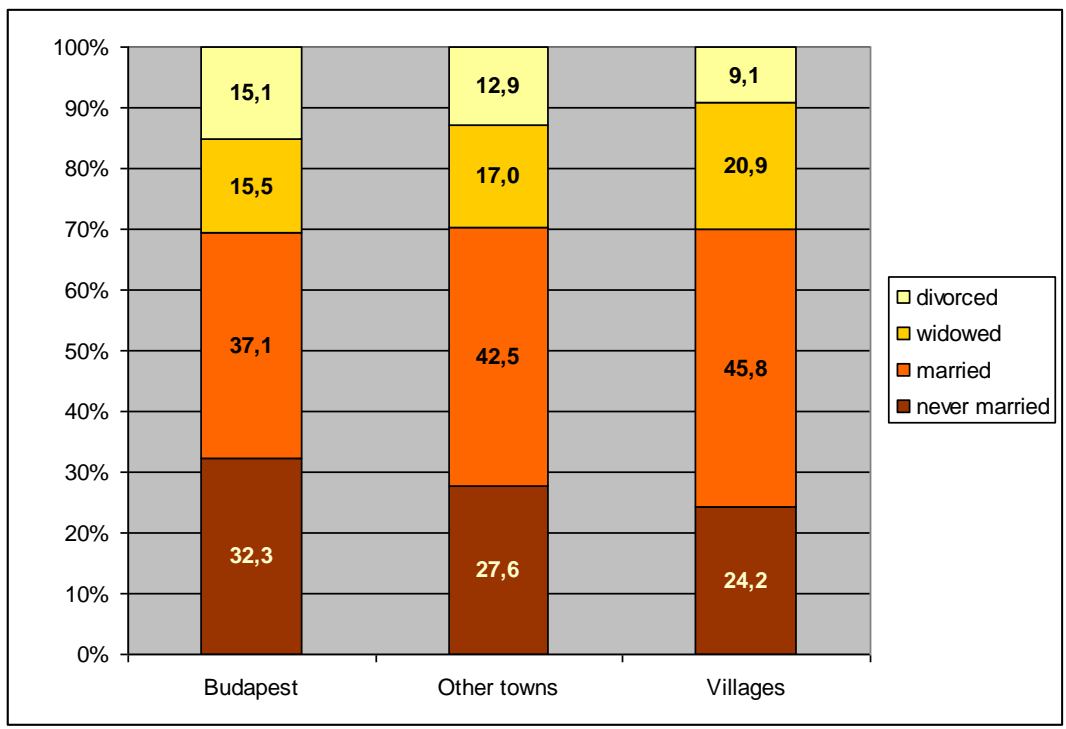

Figure 5. Percentage females (fifteen years and older) by marital status as of 1 January 2011. Source: Demographic Yearbook (2010).

\subsection{Marriage and Divorce}

In the process of more pluralistic forms of family taking shape, obviously the most striking changes have happened within marriage and other forms of cohabitation. While the number of marriages per thousand non-married females aged fifteen years or older was 62.1 in 1970, this number decreased to 13.7 in 2010. Marriage has lost its pre-eminence amongst forms of cohabitation in Hungarian society. 


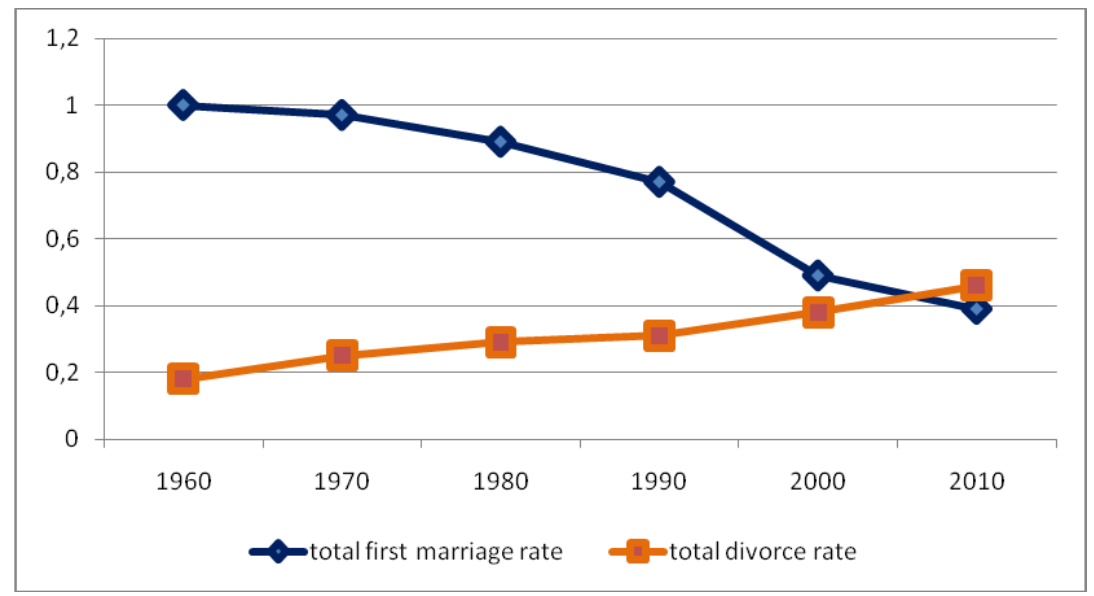

Figure 6. Total first-marriage rate for females (per hundred females) and total divorce rate (per hundred marriages). Source: Demographic Yearbook (2010).

Note: Total first-marriage rate indicates the share of males and females reaching the marrying age of fifteen years who enter marriage by a certain age (females forty-nine years, males fifty-nine years). It rests on the supposition that females and males reaching fifteen years of age will show the same disposition towards marriage as the rate of the given year. Total divorce rate indicates how many divorces occur in marriages entered in the reviewed period if the marriage-duration-specific divorce rates of the given year prevail.

The data of Figure 6 show that marriage as the only accepted family form has eroded from two directions: the diminishing number of marriages and the increasing number of divorces. However, not only the absolute number of marriages but also the marriage rate has decreased. This process started in the 1980s and accelerated after 1990. In 1960 the probability of a woman marrying at least once in her life was almost 100 per cent, but this probability has decreased to 39 per cent as of 2010 . The 1960 birth cohort reached the age of 50 in 2010 and the ratio of those never-married woman amongst them is now 7.8 per cent ${ }^{28}$.

At the same time the absolute number of divorces remained at a high level, caused by an increase in the total divorce rate. The total divorce

${ }^{28}$ Demographic Yearbook (2010) 
rate was 0.2 in 1960 but it had doubled by $2010^{29}$. It means that if the divorce rates, according to marriage duration, of 2010 does not change, almost half of new marriages will end with divorce. Nowadays in Hungary it is difficult to regard marriage as a steady life-long relationship.

The decline of marriage accompanied the growing average age at first marriage. In 1970 the average age at first marriage was 24.5 years for males and 21.8 years for females. In 2010 this is 31.4 years for males and 28.7 years for females. Those who intend to marry postpone this decision to later ages than ever before in Hungary. ${ }^{30}$ Alongside this postponement a greater proportion of young adults choose cohabitation instead of marriage. As mentioned previously, cohabitation had a negative image during the golden age of the PSF. Nowadays 70 per cent of young adults choose cohabitation for their first steady form of partner-relationship and this rate is seven times higher than it was fifty years ago. ${ }^{31}$ It is obvious that some cohabiting partners will marry in the future (especially when they decide to have children), but there can be no reliable estimate of the number. We can suppose that cohabitation will also be a widely practised family form in the future ${ }^{32}$.

The third fact which contributes to the decreasing number of marriages is that many in the younger generation do not live in steady partnerships. These young people belong to a number of groups. One group is the people living in Budapest or in the bigger cities, who are educated, and whose lifestyle is somewhat similar to single people living in Western countries. As we know from Utasi's research, ${ }^{33}$ most of them would like to have a partner, but finding a partner to match their preferences is not easy. This is especially difficult for young females, as in Hungary - just like in other European countries - more females are enrolled than males in higher education.

Another group of young people without steady partners are undereducated males living in villages. Unemployment or a lack of permanent jobs and income characterise them. Many of them are not able to start a family as they are greatly affected by the economic crisis. They remain in their parents' home in 'child-status' in statistical terms. Postponing marriage is not a choice for them but a rational answer to their life experience and poor prospects. The marriage rate of males in

\footnotetext{
29 Demographic Yearbook (2010)

${ }^{30}$ Note the relevance of Hajnal's model for this country.

${ }^{31}$ Spéder and Kapitány (2007).

32 Tóth (2007)

${ }^{33}$ Utasi (2004).
} 
different communities reflects this fact. The first-marriage rate and marriage rate in various age groups is lower amongst males living in villages compared to Budapest and other cities.

In the case of females the differences in first-marriage rate are not as sharp as in the case of males. However, we still find some differences by community type. Females in villages marry at relatively young ages just like in previous decades. Other village females who did not marry until the age of thirty have a lower chance of doing so later. Village females largely finish their first marriage 'wave' when females who are living in Budapest and in other big cities just start it, around the age of thirty.

The average duration of marriage before divorce is increasing constantly. It was 10.63 years in 1990 and 12.89 years in 2010. As in the last century, short-duration marriages were likeliest to end in divorce, but by 2010 the risk of divorce had increased in the case of longer-duration marriages too. In 2010, 39 per cent of divorces took place before the tenth year of married life, 33 per cent between ten and nineteen years, and 28 per cent after twenty years. An increasing number of longestablished marriages are dissolved every year. There is a similar trend in the age of divorce: 42 per cent of female divorcees were forty years or older in 2010 while this ratio was just 25 per cent in 2000.

Divorce is a widespread practice both in villages and cities. The only important difference is in the age of partners at the time of divorce. If a village couple has not divorced before the wife reaches thirty, they are likely to stay together. The above-mentioned phenomenon of divorce after long-lasting marriage is more typical in Budapest and the big cities.

\subsection{Marriage and Divorce: Attitudes}

As demographic data show, marriage has lost its hegemony over family forms, especially amongst the younger generation. The change of attitudes reflects this process. In 2010 half of people aged fifty years and older considered marriage the 'only acceptable partnership', while only every fourth person of the younger generation thought the same. ${ }^{34}$ Marriage has lost its hegemony but it is still highly rated in public: 80 per cent of respondents would advise young people to live in marriage according to data produced in 2009. However, at the same time a majority of people (69.7 per cent) would also advise couples to live together before getting married, ${ }^{35}$ which there denotes an increasing departure from the PSF. Data from the International Social Survey 2002

\footnotetext{
34 S. Molnár $(2011,41)$.

35 Ibid. (49).
} 
show that more than half of Hungarians agree with the statement 'Married people are generally happier than unmarried people'; among European countries surveyed, the level of agreement with that statement in Hungary was one of the highest. There was no significant difference by age group; thus, while the young in Hungary were behaving in much the same way as their Western European peers, their attitudes towards marriage were the same as their parents' attitudes. ${ }^{36}$ The most prominent research on Hungarian single people also supports the idea that Hungarian singles' main desire is to have a steady relationship, especially marriage. ${ }^{37}$

Therefore, we find that real behaviour and attitudes concerning marriage and other family forms are quite distinct but converging slowly. The spread of different family and partnership forms has preceded their public acceptance. However, the results of this modernisation and diversification of attitudes is now being realised in actual behaviour.

The consistently high number of divorces reflects public acceptance of divorce as a preferred strategy for conflict resolution in marriage. Irrespective of age or gender, 58-60 per cent of those questioned agreed with the statement: 'Divorce is usually the best solution when a couple can't seem to work out their marriage problems. ${ }^{38}$ There is general consensus across Europe on this question, the majority everywhere sharing this attitude. Thus, Hungarian views and behaviour here are in line with those in Western Europe. It is, nevertheless, important to note that despite the appearance of a few mediation organisations, Hungarian social institutions are still not sufficiently equipped to facilitate dignified divorce.

\subsection{Childbearing}

The decline of the birth rate has been an important political issue for every political regime, as the number of children per family has been falling since the beginning of the twentieth century. Even during the 'golden age' of the PSF the total fertility rate decreased to under 2.00, and this rate was just 1.32 in 2009 and 1.26 in 2010. The fertility rate in Hungary is amongst the lowest in Europe. A similarly low fertility rate can be found in Portugal and Latvia. Not only has the birth rate decreased but the childbearing habits of different birth cohorts have also changed.

\footnotetext{
36 Tóth (2006).

37 Utasi (2004).

38 International Social Survey (2002).
} 


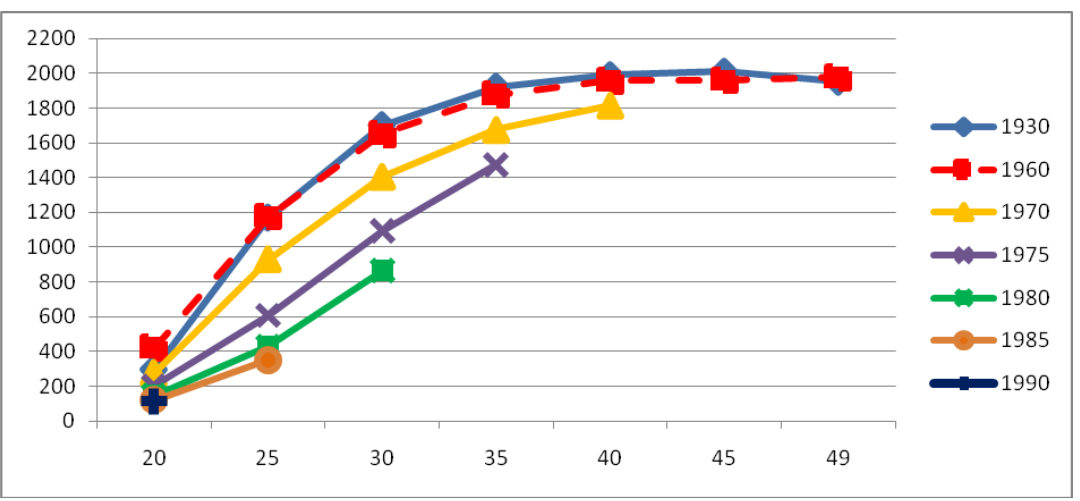

Figure 7. Average number of live-born children until given age by female birth cohort (number of live-born children per thousand females). Source: Demographic Yearbook (2010).

As Figure 7 shows, uniformity of the PSF went together with uniformity of childbearing behaviour amongst females. Total fertility in the female birth cohorts of $1930-60$ is very similar. They started childbirth in their early twenties; 1,000 females had roughly 1,200 children by the age of twenty-five. By the age of thirty-five most of them had finished childbirth and they had given birth to all their children. The total fertility rate remained under 2.0 in these cohorts but very few of these women (5-7 per cent) remained childless.

A characteristic change started with the birth cohort of 1970. Those females who were born in 1970 had just reached the age of twenty by the time of the change of regime. In previous years this age was the starting point for making a family. However, this birth cohort encountered the positive and negative effects of the new system and started to postpone the birth of their first child. Interestingly, already in 1989 when the first signs emerged of unemployment, young couples with their first child were visualising the threat of unemployment in their lives. It is obvious that many of them postponed the birth of their planned second, or later, third child. For many families this delay has resulted in fewer children than planned. Female members of the birth cohort of 1970 have just attained age forty. Biologically they may have more children but it seems most of them have now finished their period of fertility.

Postponing children is more obvious in the younger cohorts. In the younger cohorts we see older mothers at the time of the birth of their first child. The mean age of mothers at the birth of their first child was 22.99 
years in 1990, 25.02 years in 2000, and 28.23 years in $2010 .{ }^{39}$ It is possible that younger women will give birth to more children in older age and catch up to the older cohorts' fertility rate, but the financial and socio-political crisis in Hungary persists and is likely to have an impact on this. As data show the number of crèches (institutional child care facilities for children under age 3) decreased from 1003 (1990) to 530 (2005). A slight increasing started again in the last few years and for 2011 the number of crèches reached 700. (Makay 2011) However, only 9 $\%$ of children under age 3 years are attending crèches. This is a solid barrier in front of a mother to enter employment.

Mothers living in different sizes of community population show sharp differences in the total fertility rate. Total fertility rate is 1.47 in the smallest villages but is 1.09-1.10 in the biggest cities of the country and in Budapest. The very small total fertility rate of Hungary originates first of all from the demographic behaviour of women living in Budapest and other big cities. Deeper analysis of the birth rate by educational level shows that women in the middle of society, with a secondary-level education, have the lowest fertility rate. Women with poor educational levels have a much higher fertility rate and women with the highest educational level have a slightly higher fertility rate. ${ }^{40}$ This data shows the emerging pluralisation of family forms in contemporary Hungary.

The other important change concerning childbirth is the rapidly growing number of extramarital births.

\footnotetext{
39 Demographic Yearbook (2010).

${ }^{40}$ Spéder and Kapitány (2007).
} 


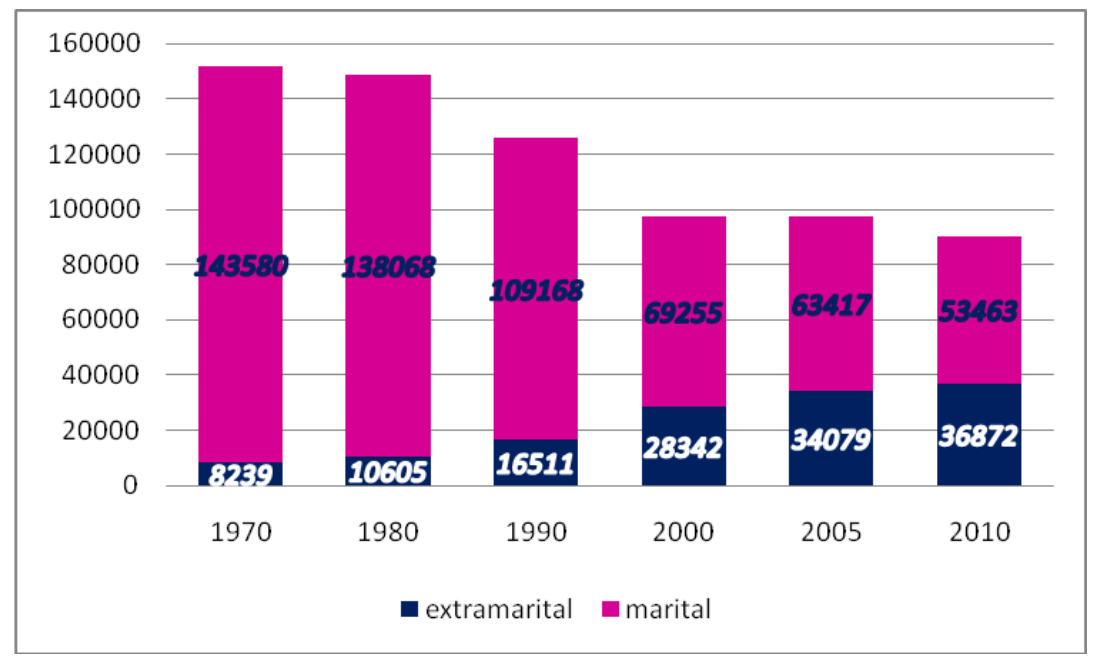

Figure 8. Number of marital and extramarital live births. Source: Demographic Yearbook (2010).

As can be seen in Figure 6 the data show that fewer than 10 per cent of children were born to parents who were not married in the 1980s; by 2010 however, the figure had risen to 41 per cent. Naturally, two-thirds of the births to those unmarried involved a couple living together and not a single mother. Together with cohabitation, Hungarians have come to accept children born outside marriage (so long as they are born to people living together as partners). However, familist demographers worry about this situation. They argue that cohabitations are less stable than marriages and that fewer children will be born from this type of relationship.

Characteristic differences can be found in the proportion of extramarital births in different community types. The smaller is the community, the higher the proportion of extramarital births. While 32.1 per cent of children were born out of wedlock in Budapest, the proportion in other towns was 40.5 per cent and in villages it was 47.5 per cent. This phenomenon is connected to the various types of marriage behaviour mentioned before: a great proportion of undereducated young people live in small villages, they are unemployed without any chance of finding a job, and therefore they postpone marriage. They live without a steady partner or they cohabit and so their children are born outside marriage. The increase in the number and ratio of extramarital births is an adaptive behaviour, a reaction to the deep economic crisis and the low levels of support for families and parents. 


\subsection{Childbearing: Attitudes}

As presented, the decline in the number of births is not a new phenomenon in Hungary. Due to the high mortality rate together with the low birth rate, there has been a natural decrease since 1981. Here the gap between real demographic behaviour and attitudes is the broadest. Attitude surveys have always shown that childcare and child rearing have consistently been highly valued by Hungarians, so it is useful to look at changes over time in the response to one particular attitude statement: 'People who have never had children lead an empty life'.

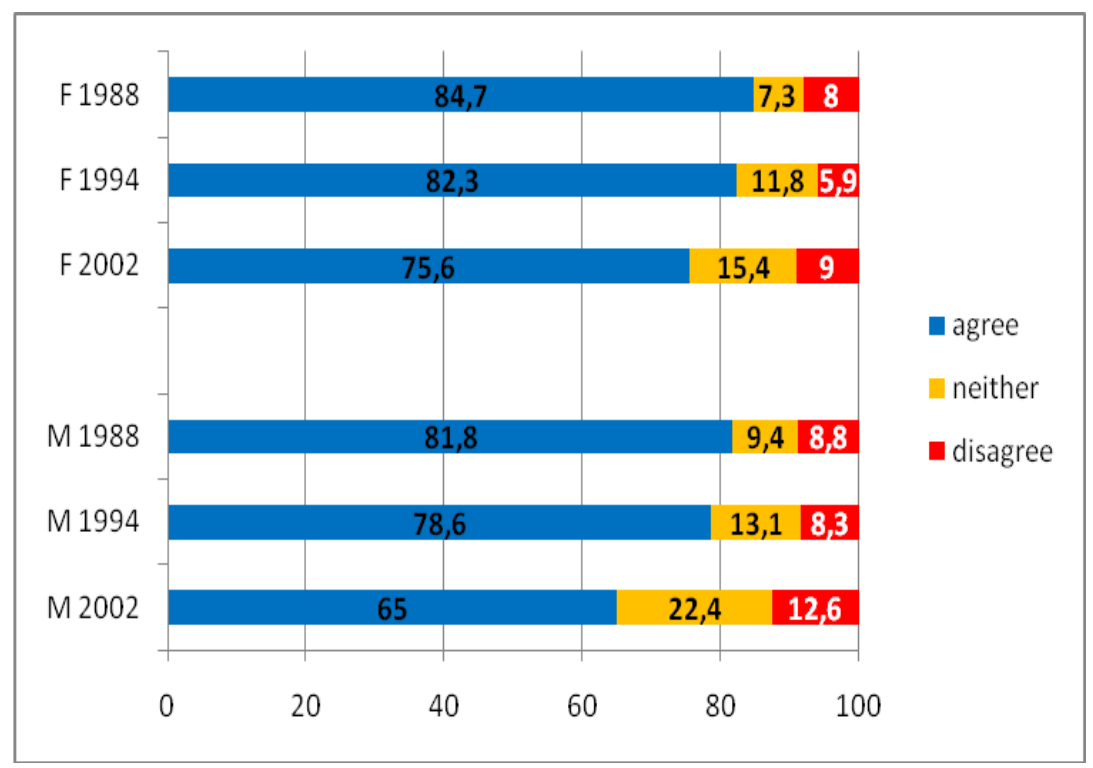

Figure 9. 'People who have never had children lead an empty life' (percentage distribution of respondents by agreement with this statement). Sources: ISSP (1988, 1994, 2002).

Note: Sample sizes in ISSP waves: ISSP (1988), N=1720; ISSP (1994), $\mathrm{N}=1500$; ISSP (2002), $\mathrm{N}=1015$

This statement expresses a categorical evaluation, since it implies that the childless experience creates an unfillable absence in people's lives. Amongst European countries, Hungary had an exceptionally high rate of respondents who agreed with this statement, well above that of other countries. However Figure 9 shows that the number of respondents who 
agree with this statement is decreasing year by year. This change is especially strong amongst males. Unfortunately the latest data is from 2002 so we can only suppose that this trend has continued. Even here, a polarisation of Hungarian society can be observed: $10-15$ per cent of the young now envision their lives without children, an opinion which has never before found such strong expression. ${ }^{41}$ Conversely there are also young people who plan on having many children, often amongst the highly educated young urban intelligentsia. Summing up we find that not only family forms but also attitudes and values concerning childbirth have started to be more pluralistic.

\section{Gender Roles: Females' Paid Work}

One of the key questions relating to gender roles is the family-work balance. During the 1980s, women in Hungary were characterised by a very high level of activity in the labour force. Not only the demands of the economy but also the ideology of the socialist regime played an important role in this level of activity. The employment rate reached its peak in 1990 when almost every women between the ages of fifteen and fifty-five was an active earner. The retirement age was lower than in most Western European countries (fifty-five for females and sixty for males), but the proportion of part-time workers was and remained until recently under 5 per cent.

\begin{tabular}{|c|c|c|c|c|c|}
\hline \multirow[t]{2}{*}{$\begin{array}{r}100,0 \% \\
80,0 \% \\
60,0 \% \\
40,0 \% \\
20,0 \% \\
0,0 \%\end{array}$} & & & & & \\
\hline & 1990 & 1997 & 2004 & 2007 & 2009 \\
\hline - Hungarian males & $83,3 \%$ & $60,3 \%$ & $63,1 \%$ & $64,0 \%$ & $61,1 \%$ \\
\hline EU Males & $75,9 \%$ & $70,6 \%$ & $70,3 \%$ & $72,5 \%$ & $70,7 \%$ \\
\hline - Hungarian females & $68,9 \%$ & $45,4 \%$ & $50,7 \%$ & $50,9 \%$ & $49,9 \%$ \\
\hline EU Females & $49,5 \%$ & $50,5 \%$ & $55,4 \%$ & $58,3 \%$ & $58,6 \%$ \\
\hline
\end{tabular}

Figure 10. Employment rates of males and females aged 15-64 in Hungary and the EU (1990-2009). Sources: Frey (1997，2011).

\footnotetext{
41 Pongrácz (2007).
} 
As Figure 10 shows, the employment rate of males and especially females was higher in Hungary than in EU countries in 1990. After the political system changed, the employment rate of women and men drastically declined due to the economic transition, so that, during a short period, one million jobs disappeared. The changes affected male employees first as a lot of women simply left the labour market, many of them choosing early retirement or withdrawal to the household. From the mid-1990s unemployment reached female employees too. ${ }^{42}$ In 2009 the employment rate for both males and females is under the European average. This fact causes problems not only at the level of the macroeconomy but also at the level of families and individuals.

As mentioned above, the PSF was typically a two-earner family. From the introduction of market-type elements into the economy in 1968, the total income of most families was supplemented with income coming from the second economy. ${ }^{43}$ Female paid work was a basic element of the family budget. The new, capitalist economy caused the closure of many workplaces and decreased the possibility of individuals getting additional income. Since 1990 social inequalities have been growing. Families typically do not have two steady incomes because the possibility of becoming unemployed is a real threat for everybody. To find a steady job is difficult especially for young people and those of lower educational levels. Families must adapt themselves to the situation, and in many cases the females are the only employed persons in the family. In this respect it is important to take into consideration the changing form of the family. There are more and more single females, divorced females, and single mothers and their personal income has primary importance for them. These facts show the importance of female employment for individuals and families, and in the light of this idea it is interesting to look at how attitudes have changed concerning female paid work.

\subsection{Gender Roles and Household Chores}

Besides female paid work, sharing household tasks is an important part of determining gender roles. As previously described, during the socialist period there was full employment for both males and females. In the meantime the development of services for doing household chores was poor. As part of the ideology of the Communist Party, the people were promised a network of cheap services in order 'to help women with household tasks'. Laundry, cleaning or food delivery services were

\footnotetext{
42 Frey (1997) and Tóth (2004)

43 Kolosi $(1987,106)$.
} 
organised under the state economy but were characterised by permanent shortages. Furthermore, the quality of these services was poor. When the marketisation of the economy started, new and high-quality services were developed, but they were too expensive for the majority of families. This resulted in housework remaining within the frame of the family and delegated to women, just as in previous historical periods. In the socialist era women worked full time and after work-hours they did the household chores too. Though a public discourse emerged from time to time about the 'second shift' of women, the question of more active participation by men in housework did not get much attention.

Relatively, the most available services were childcare institutions for children under school age. Many workplaces and also local councils ran crèches and kindergartens, but there were a lot of problems with the quality of these services. Many complained because of overcrowding, the limited opening hours, and the generally rigid care-system. Obviously it was a double-sided issue: working mothers were able to put their children into a professional and safe place while they were working, but in the meantime they struggled with continual remorse as they felt it would be better to stay at home with them. This feeling was strengthened by Hungarian psychologists, who stressed that childcare institutions were disadvantageous for all children. ${ }^{44}$

After the change of regime, state participation decreased dramatically in social services and especially in childcare institutions. Workplaces were not able to support their own crèches and kindergartens and so closed them. New market-run social services emerged but they were too expensive for a great proportion of families. Families and especially women had to find ways to manage household tasks and childcare using their own resources.

In comparison with Europe, Hungarian women spend much more time on household tasks. International Social Survey Program (ISSP) data from 2002 show that the inequality between men and women in this regard is also highly significant. Hungarian women spend 27-28 hours per week and men spend 10-11 hours per week on household chores. In the majority of families more than 75 per cent of household tasks are done by females. ${ }^{45}$ Neither his own employment status nor his wife's/partner's employment status influences a male's participation in these tasks. As sociologist Blaskó stresses: 'We cannot experience the reorganisation of tasks and the change of gender roles in cases where the family model is the opposite of the traditional one and the wife is the

\footnotetext{
44 Blaskó (2011).

45 Blaskó (2006).
} 
wage-earner. ${ }^{46}$ Females also spend far more time on housework if there is a child under the age of six in the family and if the family is living in rural surroundings. Better financial situations and higher education of females may reduce the hours spent on household tasks. There is a slight but significant effect of the attitudes of females on the amount of their household work: the more modern her attitude, the less is the time she spends on household tasks. In contrast to this, in the case of males, a modern or traditional attitude seems to have no effect on the amount of household tasks they do or the time they spend on them.

As Blaskó argues: 'Females do not lay claim to an equal share of household chores - they find it unfair only in the case of extreme inequality. ${ }^{47}$ She also says that there is little benefit in trying to 'free' women from the burden of housework as it is not a real burden for the majority of them. It would be more important to find a way for them to do part-time work, as this would make it possible for women to harmonise work and family life.

\subsection{Gender Roles and Household Chores: Attitudes}

Though Hungarian males and females share housework in a very unequal way, the majority of females (and of course males) do not find it unfair at all. As research has shown, Hungarian women are satisfied with their husbands' small contribution to household tasks. ${ }^{48}$ The main reason for this is that household chores are basically regarded as a female task. The next attitude question demonstrates how public opinion has changed over time.

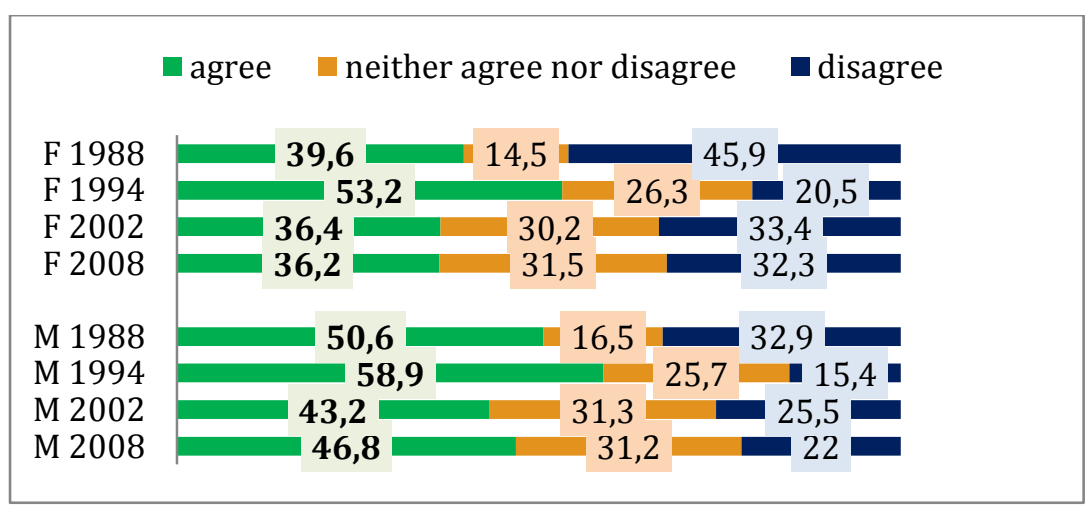

\footnotetext{
46 Ibid. (53).

47 Ibid. (92).

48 Pongrácz (2005, 84).
} 
Figure 11. 'A husband's job is to earn money; a wife's job is to look after home and family' (percentage distribution of respondents by agreement with this statement). Sources: ISSP (1988, 1994, 2002, 2008).

Note: Sample sizes in ISSP waves: ISSP (1988), N=1720; ISSP (1994), $\mathrm{N}=1500$; ISSP (2002), N=1015 ISSP (2008), N=1010

The attitude statement in Figure 11 makes a sharp distinction between gender roles, and therefore agreement with this statement expresses a very traditional view. Just like in other attitude questions, respondents place Hungary amongst the most conservative countries in every research wave. Hungarian people showed relatively the most modern attitudes in 1988. Though 50.6 per cent of males and 39.6 per cent of females agreed with the gender-specific share of roles, every third male and almost every second female disagreed with it. By 1994, after several years of economic and political changes, a more conservative view had emerged. The most radical changes happened amongst women. More than 50 per cent of them supported a traditional share of gender roles and just 20 per cent supported the modern one. From 2008 there has been a slow modernisation in attitudes concerning gender roles, but Hungarian people are far less modern in this aspect than they were during the socialist regime. The high proportion of people expressing uncertainty is also an important sign. It is not easy for people to fit their real experiences with the strengthening of the familist argument. Concerning the sharing of housework, real behaviour and people's attitudes are very similar. No gap can be found in case of males as there is a broad consensus on the 'right' division of household tasks and the majority of couples adapt to it in everyday life. In case of females more doubt is formulating but only every third persons agree with equal share of household tasks.

\subsection{Widening or Narrowing Gaps?}

Summing up, we underline the new complexity of attitudes and real behaviour concerning family types and gender roles. Hungarian people live now in more pluralistic family and other partnership forms than they did in earlier periods, and their attitudes have moved towards modernity too. However, the pace of these changes is not at all uniform. In Hungarian families the sharing of household tasks is very conservative, as are the attitudes concerning it. In Hungary the fertility rate started to decline many decades ago but attitudes about child rearing are moving only very slowly away from conservative position. Marriage became one of many forms of cohabitation, and attitudes changed towards modernity at a relatively quick pace. The most contradictory issue is that of females' 
paid work. Families and also individuals need the paid work of women or at least the income from it, but attitudes towards it remain very conservative. The broadest gap between behaviour and attitudes can be found here. It may be supposed that familist ideology keeps these conservative attitudes alive.

During the Communist era most social inequalities remained hidden. People felt that most in society were living a very similar way of life with similar opportunities. This feeling had little to do with reality in a lot of areas, but with respect to marriage and family it was not far from reality.

From the 1980s, social inequalities became more prominent in Hungarian society. What is more, new inequalities have emerged. Some of them have played an important role in the changing of family forms and of course in the changing of attitudes too. The most important can be summarised as follows:

(1) The majority of the younger generation spend a longer period in school, and as the number of students in tertiary education has increased so the number of female students in higher education has outnumbered males.

(2) Income differences split society into strata with very different life chances. Only a minority of young people are able to live a single life, maintain a one-person household, or maintain a high standard of living from one income. Meanwhile, for others, to marry and to start a family has also become an inaccessible dream.

(3) The majority of young couples realise that one or more child in the family may ruin their financial situation and/or career. To have children is not an easy decision when considering these consequences.

(4) Marketisation and the disappearance of full employment hit different social groups in a selective way. In some social groups the threat of becoming unemployed is an everyday reality for all adult members of the family.

By comparing the historical and sociological trends, we could find that, first, the chronological differences are more relevant than the spatial differences; and second, that behind the spatial differences we could point out the local appearance of other types of social inequalities. For example, the rate of marriages per 1000 by region was highest in the central parts of the county, while lowest in the eastern areas. The difference between the highest and lowest categories by region is only 16 
per cent, while the national average diminished by 25 per cent just between 2000 and 2010 (between 1990 and 2010 the decrease was 43.75 per cent).$^{49}$ However, if this rate is rearranged by counties and especially by small areas $^{50}$ the picture becomes much more sophisticated: there are areas with higher and lower marriage rates in all parts of the country. The difference between highest and lowest marriage rates in small areas is 66 per cent, but these differences are explainable better by income and educational inequalities than by spatial differences alone.

These inequalities appear in an aggregated way in the case of the Roma ethnic group. The Roma (about 5.3 per cent of the population in 2003) have suffered discrimination and social inequality of every type for a very long time, and they live, to a great extent, in spatial segregation. ${ }^{51}$ Before 1990, Roma men experienced full employment. This vanished at one stroke after the system changed: in the early 1990s only one-quarter of Roma men were full-time employees. However, the Roma/non Roma distinction has a deceptive homogenising effect: the employment of the Roma in Budapest and its outskirts has been similar to the average of the overall population, while in northern and eastern Hungary there were some small areas where the Roma are overrepresented and where this rate has sometimes approached zero.

In other areas we could find similar relationships. For example, according to comprehensive sociological studies ${ }^{52}$ the fertility of the Roma is higher than the overall average, but has begun to diminish too.

\footnotetext{
49 Demographic Yearbook (2010).

50 Today in Hungary there are seven regions, nineteen counties, and 175 small areas (kistérség).

51 Kemény et al. (2004).

${ }^{52}$ István Kemény and his collegues have produced three sets of research which cover the Roma population (Kemény et al. 2004).
} 


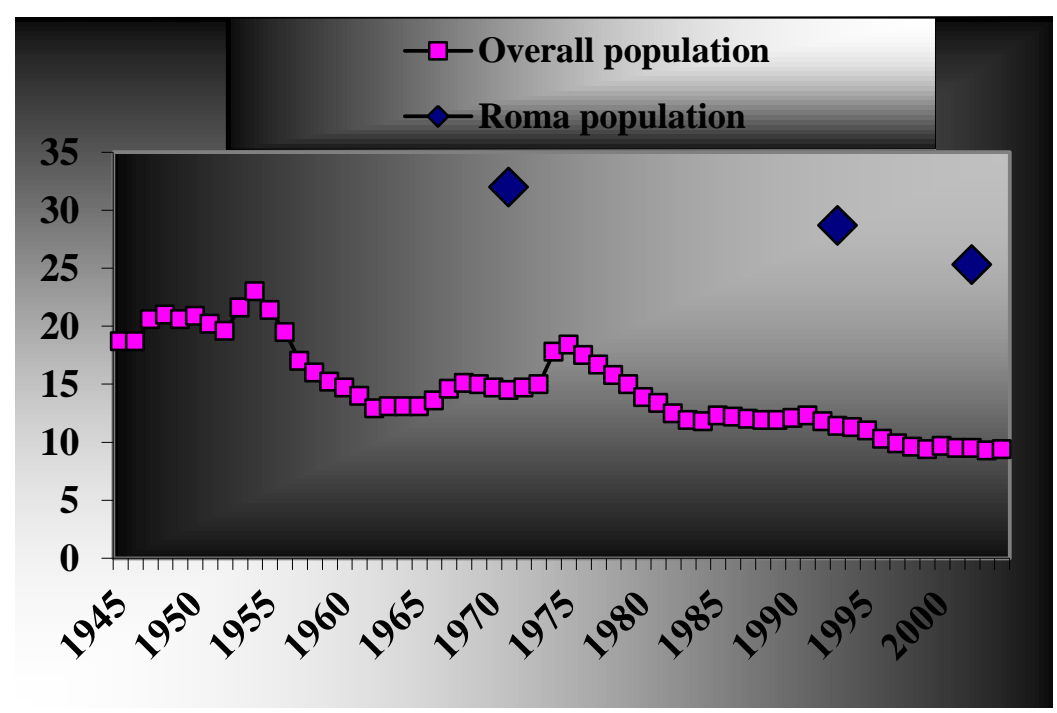

Figure 12. Number of live-born children per thousand females. Sources: Hungarian Statistical Office and Kemény et al. (2004,17).

We have to emphasis again that 'the Roma' are not as homogeneous as the non-Roma majority often thinks they are. There is a small amount of data which suggests a relationship between the demographic trends of the Roma and segregation: Roma women living in an exclusively Roma neighbourhood have significantly more children and bear their first children earlier than Roma women who live amongst the rest of society. ${ }^{53}$

János Ladányi and Iván Szelényi have found a clear relationship between the social positions of some special Roma communities, their family structure, and demographic tendencies, albeit on the basis of data from a single village. In this village, Csenyéte, the local Roma were part of the lower class in the nineteenth century, then around the beginning of the twentieth century the Roma became a segregated minority in an underclass position, then from the 1960s to 1990 they reached the relatively better but still lower position again. Meanwhile the Roma had also become the majority of the village's population. By 1990 no nonRoma lived in Csenyéte, and the whole population began to sink again into an underclass. Nowadays the number of marriages in the village is minimal and birth rates have increased. ${ }^{54}$

53 Janky (2005); Durst (2001).

${ }^{54}$ Ladányi and Szelényi (2004, 61-67). For example: a Roma woman in Csenyéte in 1881 was on average 27.1 years old when her first child was born. This value was higher than amongst the non-Roma, and it was higher than the Hajnal theory would suggest. For 


\section{Interpretation of Changes: \\ Familism and the Making of the 'Traditional Family'}

\subsection{The Concept of Familism}

We use the term of familism as a complex term which refers to a special social condition (or set of social conditions) and also to a particular ideology (though not of course in a strictly political sense). ${ }^{55}$ For simplicity this chapter will describe these two aspects as social familism and ideological familism, respectively. Every institution, legal regulation, or economic context which pushes people towards living in marriage and with family could be construed/interpreted as social familism. Every set of ideas which associates only positive values with the normative family, places the family in the centre of social discourse, which presents the family as an incubator of macro-level sociability or, with other metaphors, as the basic building-block of society; could be construed/interpreted as ideological familism. ${ }^{56}$

In the authors' view, the historical antecedents, mostly from the age of state socialism (1945-90), and then from the contemporary era since 1990 have affirmed people's inclination to live in family and to rely upon family members in preference to others. This is the origin of their social familism. This social familism is a reaction to the situation in which people are distrustful of the great institutions of state and are therefore not able to establish a strong civil society.

In theory this social condition would be independent of familist ideology, but throughout history these two phenomena have strongly tended to accompany each other. Ideological familism is a kind of 'legitimisation' of the distrust and the social passivity following from this attitude (with people largely feeling that "nowadays people can rely on only their family'). What is more, ideological familism assigns positive values to the behaviour and attitudes arising from social familism (typified by sayings such as: 'to establish a family means responsibility in the face of egoism'). ${ }^{57}$ Thus, familism responds to crises of values and, at least in theory, offers an action programme at the micro-level, that

most of the twentieth century this average was 22-24 years in the village. In the latest period when only the Roma lived in Csenyéte the mothers' average age dropped to 17.7 years (Ladányi and Szelényi 2004, 61-67).

55 Tóth and Dupcsik (2008, 2012).

${ }^{56}$ Hungarian ideological familism labeled itself as 'family centred' (családcentrikus).

${ }^{57}$ In international literature on familism, egoism and individualism have been identified by some as amoral phenomena (Banfield 1958; Fukuyama 1995; Torsello 2004). 
is, 'getting married and having children is the best strategy to integrate the whole of society.'

\subsection{Making the 'Traditional Family'}

Theoretically this normative familist 'family' could be very diverse, but in this kind of discourse a single type has emerged as 'ideal': the socalled traditional family (TF).

The image of this 'traditional family' is obviously a whole family that is made up of a married couple with children. ${ }^{58}$ This construction stresses the long-term stability of the relationship, the fixed and clearly defined gender roles, and supposes a historically strong emotional bond between family members. The ideal-type 'traditional family' is dominated by the husband, who represents the family out of home, the wife's terrain being the household and not working for pay. Children are obedient and get emotional support from their mother and moral rules from their father. According to the familist argument this ideal 'traditional family' was an almost uniform, invariable, and intact family model throughout the whole pre-1945 period (at least in villages). The same arguments stress that the social changes of the last seventy years broke this ideal family into pieces.

The TF-image is a combination of some elements of the real PSFmodel and the ideals of the familist ideology. A good example to illustrate this is the treatment of women's employment. In the implicit background of the TF-image stands the small, economically selfsufficient peasant farm. However, in the whole of early modernity only a very small fraction of the peasantry lived in conditions at all similar to this ideal. Furthermore, until 1849 serfdom still existed and even by the end of the nineteenth century less than half of the population worked in the agricultural sector. Also, before 1945 the majority of the women did paid work, in at least in some periods of their life, and the 'housewife'model was a norm only in the middle class. The new regime after 1945 was hostile to this norm and also to the former middle class. The socialist form of the economy and a social policy subordinated to its totalitarian

\footnotetext{
58 'Hungarian social anthropologists have tended to assume that in preindustrial times Hungarian peasants lived in large households containing at the same time the families of parents and several married children', wrote Andorka and Faragó $(1983,281)$ in their above cited article. Despite the authors' great authority in Hungary, their disproof of statements about the so-called 'traditional family' have not become well known, not even in the academic social sciences. However, in discourses when the 'traditional family' is used as an ideal for contemporary society, extended family characteristics are not stressed as much as the significance of 'wholeness', that is, formal marriage and more than one child.
} 
endeavours could enforce the almost full employment of women. Despite the often stressed slogans of the Communist regime that 'Work ennobles you!', the situation enhanced the feeling that women's paid work was social coercion and not an organic part of their life. This feeling has become stronger since 1990, when full employment abruptly ceased in the wake of the political change. The attitude that 'a woman's place is in the family not in the workplace' was a reaction to the decay of the PSF and the collapse of the socialist system (both of them enhanced the sense of a value crisis). It was also a good tool for males to 'legitimise' antifemale discrimination in the labour market, or for females to rationalise (in a psychological sense) their lesser chances of finding work.

As a result of the above-mentioned processes, familism as an ideology became very popular from the late 1980s/early 1990s. Thus, most people agree with the familist thesis, although meanwhile most families, as shown above, differ from this ideal. Therefore, a gap has opened between the real life of families and the attitudes/values shared by the members of these families.

According to our hypotheses one of the most important reasons for this gap is the advantage of the coherence of familist ideology. This means that familist attitudes and value-statements fit into a coherent world view. This world view seems not just to be an idea, but a valuesystem and a reality as well - because of the widely accepted idea that the 'traditional family' really existed and was a stable, long unchanged institution in spite of continuous changes in macro-level society and the political system. The TF-image is essentially a utopia - but with strong relations to reality: a (theoretically) available life-alternative because people could make themselves believe that 'my grandparents lived in such a family' and 'even I could live a similar family if I meet a suitable partner.' It is noteworthy that while the ideological divisions of the country have become more and more antagonistic, and at times fiercely divided, the traditionalism of familism is accepted in almost every section of the political spectrum.

Non-familist ideologies have lacked the coherence of familism. For multiple reasons, feminism with its egalitarian values and attitudes never really took root in Hungary, and this situation has resulted in the core discourses about the family lacking questions about women's liberation, gender equality, or, consequently, possible new roles and identities for males. The non-familist views could only really formulate their own theses in negative form, as critics of familism. Arguments such as 'the traditional family in reality was...', 'women's employment in the past was more common...', and 'it is not always the case that maintaining a 
marriage is always valuable, if...' would be correct intellectually but lack the 'sex appeal' of the familist utopia.

However, as we could see above: in recent years the gap again has become narrower: the majority of people's values/attitudes have started to follow real situations. This change has sometimes been relatively slight, as was shown in relation to women's paid work in Figure 10. Sometimes the familist opinion has moved from a majority view to a minority one, as can be seen in responses to the following statement: 'Family life suffers from the wife's full-time employment.' In 2000, 56.8 per cent of people agreed, but in 2009 only 36.6 per cent agreed (in this case the gender-specific differences are not relevant). ${ }^{59}$ Sometimes the changes have been more drastic. For example: in 1991 only 20.4 per cent agreed with the statement that: 'It's all the same for children whether their parents are married or not', but in 2009 the agreement rate was 51.7 per cent. $^{60}$

\subsection{Consistent Attitudes, Inconsistent Attitudes}

The above cited authors do not try to hide their familist involvement, and they try to fit these single-value statements into coherent value-systems. They find that after the 1990 political system change, 'consistent modern' values and attitudes were forced back while 'consistent traditional' values came forward - but these tendencies again altered in the twenty-first century.

59 Pongrácz and S. Molnár (2011, 103).

60 S. Molnár $(2011,54)$. 


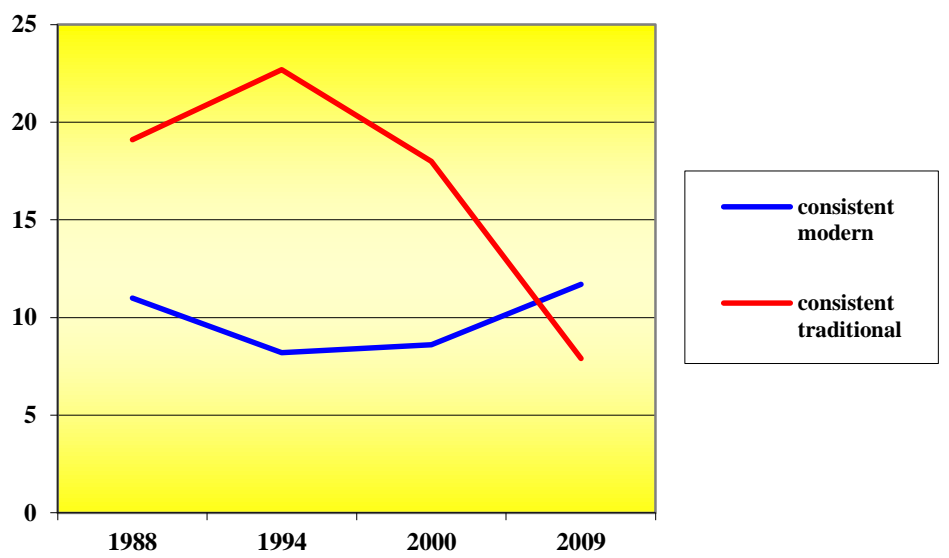

Figure 13. Consistent modern and consistent traditional values and attitudes (percentage of men and women aged between eighteen and fifty, 1988-2009). Sources: Vaskovics (2000, 292); Pongrácz and S. Molnár $(2011,109)$.

However, if we consider carefully Figure 13 it is noticeable that these two 'consistent' groups together represent only a minority of the population. The majority of people during the whole period had the attitude system treated by the researchers as incoherent or 'mixed modern-traditional', as Figure 14 shows. 


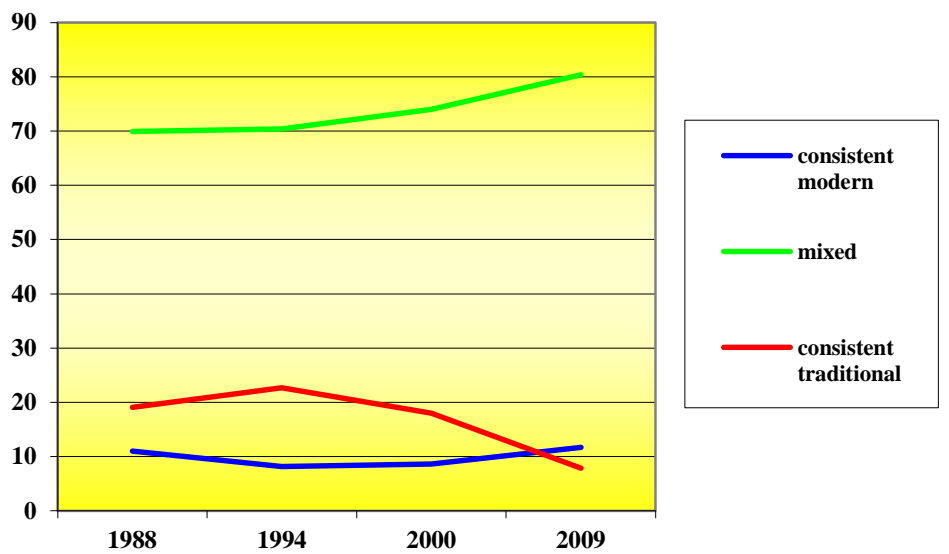

Figure 14. Modern and traditional values and attitudes (percentage of men and women aged between eighteen and fifty, 1988-2009). Sources: Vaskovics (2000, 292); Pongrácz and S. Molnár (2011, 109).

Despite the situation that more and more people could accept single statements which are incompatible with the familist norms, in discourse there always prevails what was termed above the advance of coherence. The majority live in non-familist families, but they have no voices.

\subsection{Towards a New Pluralistic Family Structure}

As was presented above, a permanent change is going on regarding family structures, gender roles, and also attitudes in contemporary Hungarian society. Familist ideology is very strong (and it is also supported by government policy) but a lot of people live in a very different way. Real behaviour and attitudes are distant from each other in the case of people with 'mixed modern-traditional' attitudes, and of course they tend to coincide in the case of some other people. It seems that classical socio-economic variables cannot give a suitable explanation of how people can reconcile their behaviour and attitudes. In Table 1 we present a hypothetical model of existing family types and their main characteristics in Hungary.

Table 1. A hypothetical model of family forms and their main characteristics. 


\begin{tabular}{|c|c|c|c|c|c|}
\hline Family type & $\begin{array}{l}\text { Does } \\
\text { the } \\
\text { female } \\
\text { work? }\end{array}$ & $\begin{array}{l}\text { Number } \\
\text { of } \\
\text { children }\end{array}$ & $\begin{array}{l}\text { Female's } \\
\text { educational } \\
\text { level }\end{array}$ & $\begin{array}{l}\text { Household } \\
\text { chores }\end{array}$ & $\begin{array}{l}\text { Conflict } \\
\text { between ideals } \\
\text { and real life }\end{array}$ \\
\hline $\begin{array}{l}\text { A. Many } \\
\text { children - } \\
\text { new type } \\
\end{array}$ & No & $3+$ & high & $\begin{array}{l}\text { Female + } \\
\text { paid help }\end{array}$ & $\begin{array}{l}\text { No conflicts - } \\
\text { conservative } \\
\text { ideals and life. }\end{array}$ \\
\hline $\begin{array}{l}\text { B. Many } \\
\text { children - } \\
\text { old type }\end{array}$ & No & $3+$ & low & $\begin{array}{l}\text { Female }+ \\
\text { extended } \\
\text { family }\end{array}$ & $\begin{array}{l}\text { No conflicts - } \\
\text { conservative } \\
\text { ideals and life. }\end{array}$ \\
\hline $\begin{array}{l}\text { C. One- } \\
\text { earner family }\end{array}$ & No & $1-2$ & low, middle & Female & $\begin{array}{l}\text { On the surface } \\
\text { no conflict - but } \\
\text { fewer children } \\
\text { then it was } \\
\text { planned and } \\
\text { may have some } \\
\text { female paid } \\
\text { work because of } \\
\text { poverty }\end{array}$ \\
\hline $\begin{array}{l}\text { D. } \\
\text { Traditional } \\
\text { two-earner } \\
\text { family }\end{array}$ & Yes & $1-2$ & middle, high & $\begin{array}{c}\text { Female + } \\
\text { male 'helps' }\end{array}$ & $\begin{array}{l}\text { Strong conflicts } \\
\text { in all spheres }\end{array}$ \\
\hline $\begin{array}{l}\text { E. One } \\
\text { person/one } \\
\text { parent family }\end{array}$ & Yes & $0,1-2$ & $\begin{array}{l}\text { low, middle, } \\
\text { high }\end{array}$ & $\begin{array}{l}\text { Adults fends } \\
\text { for } \\
\text { themselves }\end{array}$ & $\begin{array}{l}\text { Conflicts in } \\
\text { spheres of } \\
\text { partnership } \\
\text { relations and to } \\
\text { have children }\end{array}$ \\
\hline $\begin{array}{l}\text { F. Modern } \\
\text { two earner } \\
\text { family }\end{array}$ & Yes & $0,1-2$ & high & Shared & $\begin{array}{l}\text { No conflicts - } \\
\text { modern ideals } \\
\text { and life }\end{array}$ \\
\hline
\end{tabular}

The main features of these family forms are:

A. 'Many children - new type': highly educated male and female, male is well-paid entrepreneur or manager, $3+$ children, wife has no paid work at least while the children are under 10 . No conflict between conservative attitudes and real behaviour.

B. 'Many children - old type': poor, undereducated, unemployed family, they may belong to Roma ethnic minority. Little and casual income from social support or odd jobs. Female can be the head of family but when male is present he is the head without doubt. $3+$ children. They may live in extended family, but only for lack of accommodation and poverty. No conflict between conservative attitudes and real behaviour.

C. 'One earner family': female is at home with 1-2 children. Initially on childcare leave, but then after that she cannot find a job. Male's job is also in danger. Poor educational level. 
Theoretically there is no conflict between attitudes and real life but danger of poverty leads to fewer children than they planned and woman must go to work (in the case that she can).

D. 'Traditional two-earner family': this was the most common family type under socialism, and it may be the most common even now. Persons are more educated in this model than in model C. Lower number of children than it was planned earlier. Strong feeling of discrepancy between attitudes and real life.

E. 'One person/one parent family': divorced persons, singles, people living without permanent partner relationship - with or without children. He/she is working for pay. He/she experiences conflicts between attitudes and life because of a lack of permanent partner and child(ren).

F. 'Modern two-earner family': couple has modern attitudes and can live a modern lifestyle too. They have no major conflicts over these issues. Usually they have no 3 or more children as they cannot make enough money for paid help in childcare and household.

As was mentioned previously, most sociological and demographic research deals with the reasons for and consequences of the change in the 'traditional family'. It is not easy to get any funding for other types of research. Therefore, unfortunately, we have no data about the proportions of these family types in relation to the total. Nevertheless, this paper has unveiled a way to test this model, and the authors are sure that this model is good starting point for further empirical analysis. To present incidence of these types will stand in the centre of another empirical paper by authors.

\section{Conclusions}

One piece of contemporary literature by Bernadett Csurgó and Luca Kristóf, ${ }^{61}$ based on the European Social Study's data, starts 'from the preconception that value-motivated behaviour is behind the stability of a family structure and marriage, which behaviour... [is] connected to some general attitudes and values'. However, the authors are compelled to conclude that the value system has less importance in the explanations of the differences in the model, and that furthermore above all the demographic characteristics, mostly age and educational qualification cause the differences in the value system. ${ }^{, 62}$

\footnotetext{
${ }^{61}$ Csurgó and Kristóf $(2012,44)$.

${ }^{62}$ Ibid.
} 
In our view the above analysed data and tendencies are in agreement with the characteristics of the second demographic transition (SDT) being as follows: weakening of marriage as a norm, postponing the average age of the first marriage, a growing rate of single people and couples living together without marriage, and diminishing of the fertility rates. Theorists dealing with the SDT have mentioned more determinants, but they emphasise the role of changes in the value system, growing individualism, and the emergence of a 'post-materialist value system', as Ron Inglehart named it. ${ }^{63}$ According to a typical formulation, the 'innovators' of the new family lifestyles 'have often been persons with sympathies for the 'new left' during the 1960s and 1970s ... and even today premarital cohabitation has remained a correlate of secularism, tolerance for minorities, relativism in ethics, gender-equality, nonconformist education values, and a preference for leftist or green parties in countries such as Germany, France, the Netherlands and Belgium, ${ }^{64}$

In our study we have tried to demonstrate that at least in Hungary the direction of causality seems to be the opposite: the changes which are described by means of the SDT-concept occurred before the relevant changes in the value system. However, the dominant line in the discourse on family life and gender roles was familism, which explicitly tries to reverse the process.

Contemporary ideological familism is an interesting mixture of some traditional values and reminiscences about the definitely modern Postwar Standard Family, which is 'masked' in the familist discourse as the 'traditional family'. Familism is a traditionalist, not a traditional idea, but this ideology is accepted by greater proportion of the Hungarian population than is political traditionalism. According to our hypotheses the coherence of familism and the disintegration of alternative ideologies could have caused this gap. However, perhaps over the last decade this gap has begun to narrow.

\section{References}

${ }_{63}^{63}$ Lesthaeghe (2000); Spéder (2005a); Surkyn and Lesthaeghe (2004).

${ }^{64}$ Lesthaeghe $(2000,13)$. 
Andorka, Rudolf and Tamás Faragó. 1983. 'Pre-industrial Household Structure in Hungary'. In Family Forms in Historic Europe, edited by Richard Wall, Jean Robin, and Peter Laslett, 281-307. Cambridge: Cambridge University Press.

Andorka, Rudolf and István Harcsa. 1990 'Foglalkoztatás' [Employment]. In Társadalmi riport 1990 [Social report 1990], edited by Rudolf Andorka, Tamás Kolosi, and György Vukovich, 87-96. Budapest: Tárki.

Banfield, Edward C. 1958. The Moral Basis of a Backward Society. Glencoe, IL: Free Press.

Berend, T. Iván and György Ránki. 1976. Kelet-Közép-Európa gazdasági fejlödése a 19-20. században [East-Central-Europe's economic development in the 19-20th centuries]. Budapest: KJK.

-1987. Európa gazdasága a 19. században [Europe's economy in the 19th century]. Budapest: Gondolat.

Blaskó, Zsuzsa. 2006. Nök és férfiak - keresömunka, házimunka. A 'család' tematikájú ISSP 2002-es adatfelvétel elemzése [Women and men: Paid work, housework]. Budapest: Központi Statisztikai Hivatal.

Blaskó Zsuzsa 2011. 'Három évig a gyermek mellett - de nem minden áron. A közvélemény a kisgyermekes anyák munkába állásáról.' [Stay at home for three years - but not for all costs. Social values on maternal employment in Hungary].Demográfia 54:23-44.

Chang Kyung-Sup. 2003. 'The State and Families in South Korea's Compressed Fertility Transition: A Time for Policy Reversal?'. Journal of Population and Social Security (Population), supplement to Volume 1 (1972): 611-28. http://www.ipss.go.jp/webj-ad/webjournal.files/population/2003_6/21.Chang.pdf.

- 2010. South Korea under Compressed Modernity. Familial Political Economy in Transition. Abingdon: Routledge.

Csurgó, Bernadett and Luca Kristóf. 2012. 'Csak papír? Családi állapot és értékrend' [Only paper? Family status and value systems]. In Közösségi viszonyulásaink. A családdal, az állammal és a gazdasággal kapcsolatos társadalmi attitüdök, értékek európai összehasonlitásban [Our attitudes to communities. Social attitudes towards family, the state and economy], edited by Vera Messing and Bence Ságvári, 30-53. Budapest: MTA TK SZI.

Demographic Yearbook. 2010. Budapest: Központi Statisztikai Hivatal.

Diederiks, Herman A. et al. 1995. Nyugat-európai gazdaság- és társadalomtörténet. A rurális társadalomtól a gondoskodó államig [The economic and social history of Western Europe]. Budapest: Osiris.

Diószegi, István et al. 1997. 20. századi egyetemes történet III. [History of the 20th century III]. Budapest: Korona.

Durst, Judit. 2001. “Nekem ez az élet, a gyerekek.” Gyermekvállalási szokások változása egy kisfalusi cigány közösségben' [This is my life, the children]. Századvég 3: 71-92.

Faragó, Tamás. 1999. 'Háztartásszerkezet és falusi társadalomfejlödés Magyarországon, 1787-1828' [The structure of household and development in rural society in Hungary, 1787-1828]. In Tér és idö - család és történelem. Társadalomtörténeti tanulmányok [Space and time: Family and history - Social historical studies), 194-295. Miskolc: Bíbor.

Fél, Edit and Tamás Hofer. 1969. Proper Peasants: Traditional Life in a Hungarian Village. Chicago: Viking Fund Publications. 
Frey Mária. 1997. 'Nök a munkaeröpiacon.' [Women on the labour market]. In Szerepváltozások. Jelentés a nök és férfiak helyzetéröl 1997. [Changing roles. Report on the situation of women and men. 1997]. edited by Katalin Lévai and István Gy. Tóth. Budapest: TÁRKI - Munkaügyi Minisztérium,

Frey Mária. 2011. 'Nők és férfiak a munkaerőpiacon, különös tekintettel a válságkezelés hatásaira' [Women and men on the labour market - with a special stress on crisis treatment]. In Szerepváltozások. Jelentés a nök és férfiak helyzetéröl 2011. [Changing roles. Report on the situation of women and men. 2011]. edited by Ildikó Nagy and Pongrácz Tiborné. 17-48. Budapest: TÁRKI Nemzeti Erőforrás Minisztérium,

Fukuyama, Francis. 1995. Trust: The Social Virtues and the Creation of Prosperity. New York: Free Press.

Gábor, R. István and Péter Galasi. 1981. A 'második gazdaság'. Tények és hipotézisek [The 'second economy' - facts and hypotheses]. Budapest: Közgazdasági és Jogi.

Gergely, András, ed. 2003. Magyarország története a 19. Században [The history of Hungary in the 19th century]. Budapest: Osiris.

Giczi, Johanna and Endre Sik. 2009. 'Bizalom, társadalmi tőke, intézményi kötődés' [Trust, social capital and institutional commitment]. In Tárki Európai Társadalmi Jelentés [Tárki European social report], edited by I. György Tóth, 65-84. Budapest: Tárki.

Hajdu, Gábor. 2013. 'Bizalom, normakövetés és társadalmi részvétel Magyarországon a rendszerváltás után' [Trust, norms and social participation in Hungary after the system change]. In Társadalmi integráció a jelenkori Magyarországon [Social integration in contemporary Hungary], edited by Imre Kovách et al. Budapest: Argumentum.

Hajnal, John. 1965. 'European Marriage Patterns in Perspective'. In Population in History: Essays in Historical Demography, edited by David Victor Glass and David Edvard Eversley, 101-43. London: Edward Arnold (Publishers) Ltd..

1983. 'Two Kinds of Pre-industrial Household Formation System'. In Family Forms in Historic Europe, edited by Richard Wall, Jean Robin, and Peter Laslett, 65-104. Cambridge: Cambridge University Press.

Hankiss, Elemér et al. 1982. Kényszerpályán? A magyar társadalom értékrendszerének alakulása 1930 és 1980 között. I-II. [On a forced trajectory? The changes of the Hungarian society's value system between 1930 and 1980]. Budapest: MTA Szociológiai Kutató Intézet.

ISSP 1988, 1994, 2002, 2008. http://www.issp.org/page.php?pageId=4

Janky, Béla. 2005. 'A gyermekvállalás időzítése a cigány nők körében' [Timing of motherhood amongst Roma women]. Beszélö 1: 72-77.

Kemény, István. 1990. 'Munkakultúra és életforma' [Labour culture and life form]. In Velük nevelkedett a gép. Magyar munkások a hetvenes évek elején [The machine grew up with them: Hungarian workers in the beginning of the 1970s], 75-169. Budapest: Vita.

Kemény, István, Béla Janky, and Gabriella Lengyel. 2004. A magyarországi cigányság, 1971-2003 [Hungarian Roma 1971-2003]. Budapest: Gondolat - MTA Etnikai-Nemzeti Kisebbségkutató Intézet. 
Kolosi, Tamás. 1987. Tagolt társadalom. Struktúra, rétegződés, egyenlötlenség Magyarországon [Divided society. Structure, stratification and inequality in Hungary]. Budapest: Gondolat.

Kornai, János. 1980. Economics of Shortage. Amsterdam: North-Holland.

Lesthaeghe, Ron J. 2000. 'Europe's Demographic Issues: Fertility, Household Formation and Replacement Migration'. Paper prepared for the UN Expert Group Meeting on Policy Responses to Population Decline and Ageing, New York, 16-18 October.

http://www.vub.ac.be/SOCO/ron/Eur\%20Demogr\%20Issues\%20UN\%20Ned\%20 Ver\%20BuitZaken.pdf.

2008. 'Second Demographic Transition'. http://dmo.econ.msu.ru/teaching/L2/TrDemo/final_textSDTBasilBlackwellEncycl op.pdf.

Lesthaeghe, Ron J. and Dirk van de Kaa. 1986. ,Twee demografische transities?‘. In Bevolking: Groei en Krimp, edited by Dirk van de Kaa and Ron J. Lesthaeghe, 924. Deventer: Van Loghum Slaterus.

Lesthaeghe, Ron J. and Guy Moors. 1996. 'Living Arrangements, Socio-economic Position and Values among Young Adults: A Pattern Description for France, Germany, Belgium and the Netherlands'. In Europe's Population in the 1990s, edited by David Coleman, 163-221. Oxford: Oxford University Press.

Manchin, Róbert and Iván Szelényi. 1990. 'A családi mezőgazdasági termelés a kollektivizált gazdaságokban: három elmélet' [Familial agricultural production in collective estates: three theories]. In Új osztály, állam politika [New class, state policy], by Iván Szelényi, 375-98. Budapest: Európa.

Makay Zsuzsanna. 2011. 'A magyarországi bölcsödék müködésének néhány jellemzöje.' [Some characteristics of the working mechanism of crèches in Hungary]. Demográfia 2-3: 176-197

Ochiai Emiko. 1996. The Japanese Family System in Transition: A Sociological Analysis of Family Change in Postwar Japan. Tokyo: LTCB International Library Foundation.

Pongrácz, Tiborné. 2005. 'Nemi szerepek társadalmi megítélése' [Social opinion of the gender roles]. In Szerepváltozások 2005 [Role changes 2005], edited by Ildikó Nagy et al., 73-86. Budapest: TÁRKI.

- 2007. 'A gyermekvállalás, gyermektelenség és a gyermek értéke közötti kapcsolat az európai régió országaiban' [Relationship between having or not having children and the value of children in European countries). Demográfia 2: 197-219.

- ed. 2011. A családi értékek és a demográfiai magatartás változásai [Changes in family values and demographic behaviour]. Budapest: Központi Statisztikai Hivatal.

Pongrácz, Tiborné and Edit S. Molnár. 2011. 'A nemi szerepmegosztásról, a családi élet és a munka összhangjáról alkotott vélemények változása 2000-2009 között' [Changes in opinions about the division of labour in the family, and the balance of family life and paid labour, 2000-2009. In A családi értékek és a demográfiai magatartás változásai [Changes in family values and demographic behaviour], edited by Tiborné Pongrácz, 95-112. Budapest: Központi Statisztikai Hivatal.

Pongrácz, Tiborné and Zsolt Spéder. 2003. 'Élettársi kapcsolat és házasság hasonlóságok és különbségek az ezredfordulón' [Cohabiting couples and married 
couples: Similarities and differences at the turn of the millennium]. Szociológiai Szemle 4: 55-75.

S. Molnár, Edit. 2011. 'Párkapcsolat létesítését/megszüntetését érintő magatartási normák változásának megfigyelése' [Monitoring changes of norms which influenced the establishment or termination of partner relationships. In $A$ családi értékek és a demográfiai magatartás változásai [Changes in family values and demographic behaviour], edited by Tiborné Pongrácz, 37-67. Budapest: Központi Statisztikai Hivatal.

Ságvári, Bence. 2013. 'Az átmenetek kora? A magyar fiatalok társadalomképéről' [The time of transitions? Social vision of Hungarian youth]. In Integráció a jelenkori magyar társadalomban [Social integration in contemporary Hungary], edited by Imre Kovách et al., 3-47. Budapest: Argumentum.

Spéder, Zsolt. 2005a. 'Az európai családformák változatossága. Párkapcsolatok, szülői és gyermeki szerepek az európai országokban az ezredfordulón' [The variability of European family forms]. Századvég 37: 3-48.

— 2005b. 'Az élettársi kapcsolat térhódítása Magyarországon és néhány szempont a demográfiai átalakulás értelmezéséhez' [The spread of cohabitation in Hungary). Demográfia 48: 187-217.

Spéder, Zsolt and Balázs Kapitány. 2007. Gyermekek: vágyak és tények. Dinamikus termékenységi elemzések [Children: Desires and facts - Dynamic fertility analyses] Budapest: KSH.

Surkyn, Johan and Ron Lesthaeghe.2004. 'Value Orientations and the Second Demographic Transition (SDT) in Northern, Western and Southern Europe: An Update'. Demographic Research, Special Collection 3, Article 3. http://dmo.econ.msu.ru/Teaching/L2/TrDemo/value\%20orientations\%20and\%20th e\%20second\%20demographic\%20transition\%20drs3-3.pdf.

Szalai, Júlia. 2007. Nincs két ország? Társadalmi küzdelmek az állami (túl)elosztásért a rendszerváltás utáni Magyarországon [No two countries? Social struggles for state (over)redistribution in Hungary after the political change]. Budapest: Osiris.

Szelényi, Iván. 1988. Socialist Entrepreneurs: Embourgeoisement in Rural Hungary. Cambridge: Polity Press.

Therborn, Göran. 2004. Between Sex and Power. Family in the World, 1900-2000. London: Routledge.

Torsello, David. 2004. 'Bizalom, bizalmatlanság és társadalmi kapcsolatok egy délszlovákiai faluban' [Trust, distrust. and social relations in a South Slovakian village]. Szlovákiai Magyar Adatbank, Fórum Kisebbségkutató Intézet. http://www.foruminst.sk/publ/szemle/2004_3/szemle_2004_3_torsello.pdf.

Tóth, Olga.1998. 'Házasság és gyermek: vélekedés és viselkedés.' [Marriage and child: attitudes and behaviour] Századvég.11:80-93.

Tóth, Olga. 2004. 'Paid Work in Certain Periods of Family Life-Cycle in Hungary: Facts and Attitudes'. In 25th CEIES Seminar: Gender Statistics - Occupational Segregation: Extent, Causes and Consequences, 151-59. Luxemburg: Office for Official Publications of the European Communities. http://collection.europarchive.org/dnb/20070701121414/http://epp.eurostat.ec.euro pa.eu/cache/ITY_PUBLIC/KS-PB-04-001/EN/KS-PB-04-001-EN.PDF\#page=24 .

. 2006. 'Modern Behaviour, Traditional Values'. The Hungarian Quarterly 47: 85-92. 
2007. 'Fiatalok párkapcsolatai történeti háttérrel' [Partnership relations of youth in various historical periods. In Új ifjúság: Szociológiai tanulmányok a posztadoleszcensekröl [New youth. Sociological papers on postadolescents]. edited by Péter Somlai, 81-109. Budapest: Napvilág.

Tóth, Olga and Csaba Dupcsik. 2008. 'Feminizmus Helyett Familizmus' [Familism instead of feminism]. Demográfia 51: 307-28.

2012. 'Trust in People and Conservatism of Family and Gender Roles in Hungary and in Some Other European Countries'. Journal of Intimate and Public Spheres 1: 1-9.

Utasi, Ágnes. 2004. Feláldozott kapcsolatok. A magyar szingli [Sacrificed relationships: The Hungarian single]. Budapest: MTA Politikai Tudományok Intézete.

Vaskovics, László. 2000. 'A társadalmi modernizáció és a munkamegosztás a partnerkapcsolatokban és a családban. Összehasonlító vizsgálat' [Social modernisation and the division of labour in partner relationships and in family: A comparative study]. In Törések és kötések a magyar társadalomban [Breaks and bonds in Hungarian society], edited by Zsuzsa Elekes and Zsolt Spéder, 287-303. Budapest: Századvég.

Wall, Richard, Jean Robin, and Peter Laslett, eds. 1983. Family Forms in Historic Europe. Cambridge: Cambridge University Press. 